\title{
NOVEL SUPPORTED BIMETALLIC CARBIDE CATALYSTS FOR COPROCESSING OF COAL WITH WASTE MATERIALS
}

\author{
Type of report \\ Seminannual \\ Reporting Period: \\ April 1, 1998-October 30, 1998 (Second semiannual) \\ Principal Investigators: \\ Date of Report : \\ S. T. Oyama, D. F. Cox, C. Song, F. Allen \\ DOE Award Number : \\ November 4, 1998 \\ Institute: \\ DE-FG26-97FT97265 -02 \\ Virginia Polytechnic Institute \& State University \\ Department of Chemical Engineering \\ Blacksburg, VA 24061-0211 \\ Grant Date: $\quad$ October 1, 1997 \\ Contracting Officer's Rep : Uday aRao
}




\title{
NOVEL SUPPORTED BIMETALLIC CARBIDE CATALYSTS FOR COPROCESSING OF COAL WITH WASTE MATERIALS FIRST SEMIANNUAL REPORT
}

\author{
S. Ted Oyama, David F. Cox, Chunshan Song, Fred Allen
}

\section{Disclaimer}

This report was prepared as an account of work sponsored by an agency of the United States Government. Neither the United States Government nor any agency thereof, nor any of their employees, makes any warranty, express or implied, or assumes any legal liability or responsibility for the accuracy, completeness, or usefulness of any information, apparatus, product, or process disclosed, or represents that its use would not infringe privately owned rights. Reference herein to any specific commercial product, process, or service by trade name, trademark, manufacturer, or otherwise does not necessarily constitute or imply its endorsement, recommendation, or favoring by the United States Government or any agency thereof. The views and opinions of authors expressed herein do not necessarily state or reflect those of the United States

\section{Table of Contents}

Title Page

Disclaimer

Table of Contents

Executive Summary

Introduction .

Results and Discussion

Conclusions

Future Work .

Papers Published

References 


\section{Executive Summary}

A new family of bimetallic oxynitride compounds, $\mathrm{M}_{\mathrm{I}^{-}} \mathrm{M}_{\mathrm{II}}-\mathrm{O}-\mathrm{N}\left(\mathrm{M}_{\mathrm{I}}, \mathrm{M}_{\mathrm{II}}=\mathrm{Mo}, \mathrm{W}, \mathrm{V}, \mathrm{Nb}\right.$, $\mathrm{Cr}, \mathrm{Mn}$ and $\mathrm{Co}$ ), has been synthesized by nitriding bimetallic oxide precursors with ammonia gas via a temperature programmed reaction. The oxide precursors are prepared by conventional solid state reaction between two appropriate monometallic oxides. The synthesis involves passing $\mathrm{NH}_{3}$ gas over the oxide precursors at a flow rate of $6.80 \times 10^{2} \mu \mathrm{mol} \mathrm{s}-1\left(1000 \mathrm{~cm}^{3} / \mathrm{min}\right)$, and raising the temperature at a heating rate of $8.3 \times 10^{-2} \mathrm{~K} \mathrm{~s}^{-1}(5 \mathrm{~K} / \mathrm{min})$ to a final temperature $\left(\mathrm{T}_{\mathrm{f}}\right)$ which is held constant for a short period of time ( $\left.\mathrm{t}_{\text {hold }}\right)$. The oxynitrides thus obtained are pyrophoric and need to be passivated before exposing them to air. All these new bimetallic oxynitrides have a face centered cubic (fcc) crystal structure and high values of surface area. The surface reactivation and the thermal stability of the materials are studied by temperature programmed reduction (TPR) and this indicates that the compounds can be divided into three groups of different reducibility (high, medium, low). Their surface activity and surface area are evaluated based on $\mathrm{CO}$ chemisorption and $\mathrm{N}_{2}$ physisorption measurements. It is found that the chemisorbed $\mathrm{CO}$ number density correlates with the reducibility of the compounds.

The bimetallic catalysts were studied in hydroprocessing at realistic conditions (3.1 MPa and $643 \mathrm{~K}$ ). Activity also correlated with reducibility of the compounds. A V-Mo composition had greater HDN conversion than a commercial Ni-Mo sulfide catalyst.

\section{Introduction}

Transition metal nitrides have received considerable attention as catalysts, in particular, for their activity in hydrogenation [1,2], hydrodenitrogenation (HDN) and hydrodesulfurization (HDS) $[3,4]$. Their activities resemble those of the noble Group 8-10 metals (Pt, Pd, Rh, etc.), and in some cases they have superior selectivity, stability and resistance to poisoning [5].

Monometallic nitrides have been investigated extensively since the 50's and 60's. Studies reveal that their phases can exist over broad composition ranges with appreciable vacancy concentrations, and that their physical properties are quite sensitive to composition. Compared to monometallic nitrides, relatively few transition metal bimetallic nitrides have been synthesized and fully characterized [6,7]. For catalytic applications it is critical for a material to have high specific surface area $\left(\mathrm{S}_{\mathrm{g}}\right)$. Conventional powder metallurgy methods such as direct nitridation of metal powders do not yield high surface area products because of the elevated temperatures necessary for reaction. In the early 80's a new preparation method, referred to as temperature programmed reaction, was developed which produces carbides and nitrides with high specific surface areas. In nitride preparation, the method involves placing an oxide precursor in a flowing ammonia stream while raising the temperature in a controlled manner.

In the current reporting period, the temperature programmed reaction technique is applied to bimetallic oxide precursors, prepared by solid state reaction. The bimetallic nitride products are surface active. They all adopt face centered cubic (fcc) crystal structure and have high surface area. 


\section{Results and Discussion}

\section{Synthesis}

Bimetallic oxide precursors were prepared by the solid state reaction of two monometallic oxides. In all cases one of the oxides was $\mathrm{MoO}_{3}$ or $\mathrm{WO}_{3}$. The two monometallic oxides, at a prechosen metal ratio, were thoroughly intermixed by grinding, pelletized and fired in air at various final temperatures (Table 1) for 6 hours. The temperatures were chosen so that complete reaction of the constituent oxides occurred, as verified by x-ray diffraction. After firing, the solid products were pulverized into fine powders. The bimetallic oxide powders synthesized were individually transferred to a quartz reactor, which was placed inside a tubular resistance furnace, whose temperature was raised at a linear rate of $8.3 \times 10^{-2} \mathrm{~K} \mathrm{~s}^{-1}(5 \mathrm{~K} / \mathrm{min})$ to a final setting $\left(\mathrm{T}_{\mathrm{f}}\right)$ which was held for a period of time $\left(\mathrm{t}_{\text {hold }}\right)$. An ammonia gas stream was passed through the oxide powders during the reaction at a flow rate of $6.80 \times 10^{2} \mu \mathrm{mol} \mathrm{s}^{-1}\left(1000 \mathrm{~cm}^{3} / \mathrm{min}\right)$. Table 1 summarizes the synthesis conditions to produce a pure phase for both bimetallic oxides and bimetallic oxynitrides. Each material required different conditions, and these were found by careful variation of the synthesis parameters (time and temperature). After the temperature programmed reaction, the oxynitride samples were passivated at room temperature, using a gas mixture containing $0.5 \% \mathrm{O}_{2}$ in $\mathrm{He}$ at a flow rate of $24 \mu \mathrm{mol} \mathrm{s}-1\left(35 \mathrm{~cm}^{3} / \mathrm{min}\right.$.). The time of passivation was set to 3 hours per gram of starting bimetallic oxide used.

TABLE 1

Preparation Conditions for Bimetallic Oxides and Oxynitrides

\begin{tabular}{|c|c|c|c|c|c|c|}
\hline & & & \multicolumn{2}{c|}{ Synthesis of oxides } & \multicolumn{2}{c|}{ Synthesis of oxynitrides } \\
\hline $\begin{array}{c}\text { System } \\
\left(\mathrm{M}_{\mathrm{I}}-\mathrm{M}_{\mathrm{II}}\right)\end{array}$ & $\begin{array}{c}\text { Starting } \\
\text { Materials }\end{array}$ & $\begin{array}{c}\text { Metal Ratio } \\
\left(\mathrm{M}_{\mathrm{I}}: \mathrm{M}_{\mathrm{II}}\right)\end{array}$ & $\begin{array}{c}\text { Firing } \\
\text { Temp. } \\
\left(\mathrm{T}_{\mathrm{MAX}}\right)\end{array}$ & $\begin{array}{c}\text { Time Hold } \\
\text { at } \mathrm{T}_{\mathrm{MAX}}\end{array}$ & $\begin{array}{c}\text { Final } \\
\text { Temp. } \\
\left(\mathrm{T}_{\mathrm{MAX}}\right)\end{array}$ & $\begin{array}{c}\text { Time Hold } \\
\text { at } \mathrm{T}_{\mathrm{MAX}} \\
\left(\mathrm{t}_{\text {hold }}\right)\end{array}$ \\
\hline $\mathrm{V}-\mathrm{Mo}$ & $\mathrm{V}_{2} \mathrm{O}_{5}-\mathrm{MoO}_{3}$ & $2: 1$ & $948 \mathrm{~K}$ & $6 \mathrm{~h}$ & $1037 \mathrm{~K}$ & 30 min. \\
$\mathrm{Nb}-\mathrm{Mo}$ & $\mathrm{Nb}_{2} \mathrm{O}_{5}-\mathrm{MoO}_{3}$ & $2: 3$ & $1058 \mathrm{~K}$ & $6 \mathrm{~h}$ & $1063 \mathrm{~K}$ & 20 min. \\
$\mathrm{Cr}-\mathrm{Mo}$ & $\mathrm{Cr}_{2} \mathrm{O}_{3}-\mathrm{MoO}_{3}$ & $1: 1$ & $1058 \mathrm{~K}$ & $6 \mathrm{~h}$ & $1013 \mathrm{~K}$ & 20 min. \\
$\mathrm{Mn}-\mathrm{Mo}$ & $\mathrm{Mn}_{3} \mathrm{O}_{4}-\mathrm{MoO}_{3}$ & $1: 1$ & $1013 \mathrm{~K}$ & $6 \mathrm{~h}$ & $935 \mathrm{~K}$ & $36 \mathrm{~min}$. \\
$\mathrm{Co}-\mathrm{Mo}$ & $\mathrm{CoC}_{2} \mathrm{H}_{6} \mathrm{O}_{4}-\mathrm{MoO}_{3}$ & $1: 1$ & $1058 \mathrm{~K}$ & $6 \mathrm{~h}$ & $892 \mathrm{~K}$ & 20 min. \\
$\mathrm{Nb}-\mathrm{W}$ & $\mathrm{Nb}_{2} \mathrm{O}_{5}-\mathrm{WO}_{3}$ & $2: 3$ & $1323 \mathrm{~K}$ & $6 \mathrm{~h}$ & $1113 \mathrm{~K}$ & $24 \mathrm{~min}$. \\
$\mathrm{V}-\mathrm{W}$ & $\mathrm{V}_{2} \mathrm{O}_{5}-\mathrm{WO}_{3}$ & $1: 1$ & $1323 \mathrm{~K}$ & $6 \mathrm{~h}$ & $1009 \mathrm{~K}$ & $110 \mathrm{~min}$. \\
$\mathrm{Mo}-\mathrm{W}$ & $\mathrm{MoO}_{3}-\mathrm{WO}_{3}$ & $1: 1$ & $1058 \mathrm{~K}$ & $6 \mathrm{~h}$ & $991 \mathrm{~K}$ & 20 min. \\
$\mathrm{Co}-\mathrm{W}$ & $\mathrm{Co}_{3} \mathrm{O}_{4}-\mathrm{WO}_{3}$ & $1: 1$ & $1370 \mathrm{~K}$ & $6 \mathrm{~h}$ & $1063 \mathrm{~K}$ & $24 \mathrm{~min}$. \\
\hline
\end{tabular}

Both bimetallic oxides and bimetallic oxynitrides was analyzed by x-ray diffraction (XRD), using a Siemens Model D 500 diffractometer with a $\mathrm{CuK} \alpha$ monochromatized radiation source, for phase identification. The prominent features of each product's XRD pattern, i.e. peak position and intensity, do not match those of the parent oxides, nor their reduced forms. The results suggest that at least the major phases of the products are true bimetallic oxides, instead of mechanical mixtures of the starting oxides. The results indicate, interestingly, that all the oxynitrides thus synthesized have a face centered cubic (fcc) metallic arrangement. The XRD peak d-spacings and their indexing are listed in Table 2. Furthermore, the broadening of the XRD 
peaks indicates that these oxynitrides have very small crystallite sizes, which in turn suggests high surface areas in these materials.

The bimetallic oxynitrides were also characterized by inductively coupled plasma (ICP) for elemental composition. The results are presented in Table 3.

TABLE 2

XRD Peak d-Spacing and Indexing of Bimetallic Oxynitrides

\begin{tabular}{|c|c|c|c|c|c|}
\hline Indexing & ( 111 ) & $(200)$ & $(220)$ & ( 311$)$ & ( 222 ) \\
\hline Compounds & \multicolumn{5}{|c|}{ d-spacing } \\
\hline V-Mo-O-N & 2.38 & 2.06 & 1.46 & 1.24 & 1.19 \\
\hline Nb-Mo-O-N & 2.45 & 2.11 & 1.50 & 1.27 & 1.22 \\
\hline Cr-Mo-O-N & 2.38 & 2.06 & 1.46 & 1.25 & 1.19 \\
\hline Mn-Mo-O-N & 2.52 & 2.18 & 1.54 & - & - \\
\hline Co-Mo-O-N & 2.43 & 2.10 & 1.49 & - & - \\
\hline $\mathrm{Nb}-\mathrm{W}-\mathrm{O}-\mathrm{N}$ & 2.41 & 2.09 & 1.48 & 1.26 & - \\
\hline V-W-O-N & 2.39 & 2.06 & 1.46 & 1.25 & 1.20 \\
\hline Mo-W-O-N & 2.40 & 2.07 & 1.47 & 1.25 & - \\
\hline Co-W-O-N & 2.40 & 2.05 & 1.46 & 1.25 & - \\
\hline
\end{tabular}

TABLE 3

Molar Composition of Bimetallic Oxynitride $\mathrm{M}_{\mathrm{w}}^{\mathrm{I}} \mathrm{M}^{\mathrm{II}}{ }_{\mathrm{x}} \mathrm{O}_{\mathbf{y}} \mathbf{N}_{\mathrm{z}}$ (from elemental analysis)

\begin{tabular}{|c|c|c|c|c|c|c|c|c|c|c|}
\hline$\underline{\text { sample }}$ & $\begin{array}{c}\mathrm{M}^{\mathrm{I}}: \mathrm{M}^{\mathrm{II}} \\
\text { (theoretical) }\end{array}$ & $\underline{\mathrm{V}}$ & $\underline{\mathrm{Nb}}$ & $\underline{\mathrm{Cr}}$ & $\underline{\mathrm{Mn}}$ & $\underline{\mathrm{Co}}$ & $\underline{\mathrm{Mo}}$ & $\underline{\mathrm{W}}$ & $\underline{\mathrm{O}}$ & $\underline{\mathrm{N}}$ \\
\hline V-Mo-O-N & $2: 1$ & 2.0 & & & & & 1.0 & & 1.7 & 2.4 \\
Nb-Mo-O-N & $2: 3$ & & 2.0 & & & & 2.6 & & 3.0 & 4.2 \\
Cr-Mo-O-N & $1: 1$ & & & 1.0 & & & 1.3 & & 2.3 & 1.4 \\
Mn-Mo-O-N & $1: 1$ & & & & 1.0 & & 1.0 & & 1.5 & 0.88 \\
Co-Mo-O-N & $1: 1$ & & & & & 1.0 & 1.0 & & 1.6 & 0.79 \\
Nb-W-O-N & $2: 3$ & & 2.0 & & & & & 2.8 & 4.6 & 5.1 \\
V-W-O-N & $1: 1$ & 1.0 & & & & & & 1.4 & 2.7 & 2.5 \\
Mo-W-O-N & $1: 1$ & & & & & & 1.0 & 1.0 & 2.4 & 2.1 \\
Co-W-O-N & $1: 1$ & & & & & 1.0 & & 1.0 & 1.2 & 1.0 \\
\hline
\end{tabular}

$\mathrm{CO}$ chemisorption was used to titrate the surface metal atoms in the sample. After a two hour reduction, pulses of $\mathrm{CO}$ gas were introduced through a sampling valve with a He carrier gas 
stream passing over the samples. The total uptake was calculated by referring the areas under the $\mathrm{CO}$ mass signal (28) peaks to the known quantity of $12 \mu \mathrm{mol} \mathrm{CO}$ for a single peak.

Surface areas were determined immediately after the $\mathrm{CO}$ uptake measurements by a similar flow technique using a $30 \% \mathrm{~N}_{2}$ in He gas mixture passed over the samples maintained at liquid nitrogen temperature. The amount of physisorbed $\mathrm{N}_{2}$ was obtained by comparing the area of the desorption peaks to the area of calibrated $\mathrm{N}_{2}$ pulses containing $38 \mu \mathrm{mol} \mathrm{N} / 2$ pulse. The surface area was then calculated from the single point BET equation.

Table 4 summarizes the $\mathrm{CO}$ uptakes, surface areas and the active site density of the oxynitrides, together with their crystallite size and particle size. The crystallite size $\left(\mathrm{D}_{\mathrm{c}}\right)$ was calculated by the Scherrer equation, based on XRD peak broadening. The particle size $\left(\mathrm{D}_{\mathrm{p}}\right)$ was calculated from the equation: $D_{p}=6 /\left[S_{g} \rho\right]$, where $\rho$ is taken to be $10.2 \mathrm{~g} \mathrm{~cm}^{-3}$ for Mo oxynitride compounds and $18.9 \mathrm{~g} \mathrm{~cm}^{-3}$ for $\mathrm{W}$ oxynitride compounds, assuming perfect rock salt structures for these compounds.

TABLE 4

\section{Characteristics of Bimetallic Oxynitrides}

\begin{tabular}{|c|c|c|c|c|c|c|c|}
\hline Compounds & $\begin{array}{l}\text { Reducibility } \\
\text { (from TPR) }\end{array}$ & $\begin{array}{l}\text { CO uptake } \\
(\mu \mathrm{mol} \mathrm{g}-1)\end{array}$ & $\begin{array}{c}\text { Surface } \\
\text { Area } \\
\left(\mathrm{S}_{\mathrm{g}} \mathrm{m}^{2} \mathrm{~g}^{-1}\right)\end{array}$ & \multicolumn{2}{|c|}{$\begin{array}{l}\text { Site Density } \\
\text { ( x } 10^{15} \mathrm{~cm}^{-2} \text { ) }\end{array}$} & $\begin{array}{l}\text { Particle } \\
\text { Size } \\
\mathrm{D}_{\mathrm{p}}(\mathrm{nm})\end{array}$ & $\begin{array}{c}\text { Crystallite } \\
\text { Size } \\
\mathrm{D}_{\mathrm{c}}(\mathrm{nm})\end{array}$ \\
\hline V-Mo-O-N & High & 167 & 74 & 0.14 & $\mathrm{H}$ & 7.9 & 11 \\
\hline Cr-Mo-O-N & High & 163 & 90 & 0.11 & $\mathrm{H}$ & 6.6 & 3.9 \\
\hline Co-Mo-O-N & High & 186 & 103 & 0.11 & $\mathrm{H}$ & 5.7 & 4.5 \\
\hline Mo-W-O-N & Mod & 59.8 & 118 & 0.031 & M & 5.0 & 6.5 \\
\hline $\mathrm{Nb}-\mathrm{W}-\mathrm{O}-\mathrm{N}$ & Mod & 32.7 & 81 & 0.024 & M & 3.9 & 5.2 \\
\hline Co-W-O-N & Mod & 12.5 & 45 & 0.017 & M & 7.1 & 3.8 \\
\hline Mn-Mo-O-N & Mod & 10.6 & 37 & 0.017 & M & 15.8 & 3.5 \\
\hline V-W-O-N & Low & 9.67 & 62 & 0.0094 & $\mathrm{~L}$ & 5.1 & 6.7 \\
\hline Nb-Mo-O-N & Low & 11.2 & 121 & 0.0056 & $\mathrm{~L}$ & 4.9 & 5.3 \\
\hline
\end{tabular}

\section{Reactivity}

The bimetallic oxynitrides were used as catalysts in hydrotreating reactions at 3.1 MPa and $643 \mathrm{~K}$ in a three-phase trickle-bed reactor. The feed was a model liquid mixture containing 3000 ppm sulfur (dibenzothiophene), 2000 ppm nitrogen (quinoline), 500 ppm oxygen (benzofuran), 20 $\mathrm{wt} \%$ aromatics (tetralin) and balance aliphatics (tetradecane). The activities of the bimetallic nitrides were compared to a commercial sulfided $\mathrm{Ni}-\mathrm{Mo} / \mathrm{Al}_{2} \mathrm{O}_{3}$ catalyst tested at the same conditions. The bimetallic oxynitrides were active for $\mathrm{HDN}$ of quinoline with V-Mo-O-N showing higher HDN activity than the commercial sulfided Ni-Mo-S/ $/ \mathrm{Al}_{2} \mathrm{O}_{3}$ catalyst. The HDS activity of the bimetallic oxynitrides ranged from 9-37 \% with Co-Mo-O-N showing the highest HDS activity among the oxynitrides tested. X-ray diffraction analysis of the spent catalysts indicated that the oxynitrides consisting of early transition metals (Group 4-Group 6) were 
tolerant of sulfur, while catalysts involving metals of Group 7 and Group 8 showed bulk sulfide phases. X-ray photoelectron spectroscopic analysis of the catalysts before and after the reaction indicated the incorporation of sulfur on the surface of the catalysts after prolonged exposure to the reactants.

\section{Conclusions}

A new catalyst series, $\mathrm{M}_{\mathrm{I}}-\mathrm{M}_{\mathrm{II}} \mathrm{O}-\mathrm{N}\left(\mathrm{M}_{\mathrm{I}}, \mathrm{M}_{\mathrm{II}}=\mathrm{Mo}, \mathrm{W}, \mathrm{V}, \mathrm{Nb}, \mathrm{Cr}, \mathrm{Mn}\right.$ and $\left.\mathrm{Co}\right)$, has been prepared by a temperature programmed reaction process. The temperatures required for the synthesis are moderate $(<1120 \mathrm{~K})$, the cycles are short (moderate heating rate and holding times), and the parameters are easy to control. The oxide precursors used for making these oxynitrides are prepared by conventional solid state reaction using common starting materials.

The bimetallic oxynitrides were found to possess excellent HDN activity, and in particular, V-Mo-O-N showed better HDN activity than the commercial sulfided $\mathrm{Ni}-\mathrm{Mo} / \mathrm{Al}_{2} \mathrm{O}_{3}$ catalyst. Bimetallic oxynitrides with molybdenum as one of the metals showed higher activity than the corresponding monometallic nitrides. Molybdenum or tungsten alloyed with early transition metals ( $\mathrm{V}, \mathrm{Nb}, \mathrm{Cr}$ ) were sulfur tolerant, while $\mathrm{Mn}$ and Co alloys were sulfur sensitive and showed bulk sulfidation. The activity results are promising and further work needs to be carried out to optimize the ratio of the concentration of metals in the bimetallic compounds.

\section{Future Work}

We will continue the development of new catalysts, this time concentrating on bimetallic carbides. We will carry out preliminary investigations of the compounds in hydrotreating before attempting the more difficult plastic and rubber reactions.

\section{Papers Published}

1. New Catalysts for Hydroprocessing: Bimetallic Oxynitrides $\mathrm{M}_{\mathrm{I}^{-}}-\mathrm{M}_{\mathrm{II}} \mathrm{O}-\mathrm{N}\left(\mathrm{M}_{\mathrm{I}}, \mathrm{M}_{\mathrm{II}}=\mathrm{Mo}\right.$, $\mathrm{W}, \mathrm{V}, \mathrm{Nb}, \mathrm{Cr}, \mathrm{Mn}$, and Co) Part I: Synthesis and Characterization.

C. C. Yu, S. Ramanathan and S. T. Oyama

J. Catal. 1998, 173, 1.

2. New Catalysts for Hydroprocessing: Bimetallic Oxynitrides $\mathrm{M}_{\mathrm{I}}-\mathrm{M}_{\mathrm{II}}-\mathrm{O}-\mathrm{N}\left(\mathrm{M}_{\mathrm{I}}, \mathrm{M}_{\mathrm{II}}=\mathrm{Mo}\right.$, W, V, Nb, Cr, Mn, and Co) Part II: Reactivity Studies.

C. C. Yu, S. Ramanathan and S. T. Oyama

J. Catal. 1998, 173, 10.

3. Synthesis, Characterization and Reactivity Studies of Supported $\mathrm{Mo}_{2} \mathrm{C}$ with Phosphorus Additive

B. Dhandapani, S. Ramanathan, C. C. Yu, J. G. Chen, and S. T. Oyama

J. Catal. 1998, 176, 61. 


\section{References}

1. Ranhotra, G. S., Haddix, G. W., Bell, A. T., and Reimer, J. A., J. Catal. 108, 24 (1987)

2. Ranhotra, G. S., Bell, A. T., and Reimer, J. A., J. Catal. 108, 40 (1987).

3. Markel, E. J., and Van Zee, J. W., J. Catal. 126, 643 (1990).

4. Ramanathan, S., and Oyama, S. T., J. Phys. Chem. 99, 16365 (1995).

5. Boudart, M., Oyama, S. T., and LecLercq, L., Proc. 7th Int. Cong. Catal. Tokyo, 1980, Seiyama, T., and Tanabe, K., Eds., Vol. 1, p. 578, Kodansha, 1980.

6. Bem, D. S., and Zur Loye, H. C., J. Solid State Chem. 104, 467 (1993).

7. Yamamoto, T., Kikkawa, S., and Kanamaru, F., Solid State Ionics 148, 63 (1993). 